\title{
Role of Otoacoustic Emissions and Auditory Brainstem Response for Early Detection of Hearing Loss in Children 0-3 Months of Age
}

\author{
Hemant Gupta', Smriti Anand ${ }^{2}$, Neelam Grover ${ }^{3}$, Vipen Gupta ${ }^{4}$, Deepika Sharma ${ }^{5}$ \\ ${ }^{1}$ Assistant Professor, Department of Pediatrics, Maharishi Markandeshwar Medical College and Hospital Kumarhatti, Solan, ${ }^{2}$ Associate Professor, Department of \\ Anaesthesia, Maharishi Markandeshwar Medical College and Hospital Kumarhatti, Solan, ${ }^{3}$ Professor, Department of Pediatrics, Maharishi Markandeshwar Medical College \\ and Hospital Kumarhatti, Solan, ${ }^{4}$ Professor, Department of Otorhinolaryngology, Maharishi Markandeshwar Medical College and Hospital Kumarhatti, Solan, ${ }^{5}$ Audiologist, \\ Department of Otorhinolaryngology, Maharishi Markandeshwar Medical College and Hospital Kumarhatti, Solan.
}

\section{Abstract}

Background: Hearing impairment has a huge adverse impact on the normal developmental outcome of an individual. The various newborn period risk factors may escalate hearing loss. Early detection of hearing impairment has been made possible with the use of universal tools like OAE (Otoacoustic emission) and ABR (Auditory brainstem response) and has resulted in the general awareness and timely intervention. This study highlights the use of OAE and ABR for early detection of hearing loss in children 0-3 months along with the associated risk factors taken into consideration. Subjects and Methods: The present study was conducted in Maharishi Markandeshwar medical college and hospital over a period of 12 months and included 1680 newborns who were subjected to two staged OAE examination( pre discharge and at 6 weeks) followed by ABR examination done over a period of 3 months. The various risk factors were also evaluated. Results: A total of 1680 newborns underwent pre discharge first OAE examination, 146(8.7\%) failed. A total of 141 underwent the repeat OAE examination at 6 weeks and 23(16.3\%) failed. ABR examination of 20 children resulted in failure in 3(15\%) culminating in overall prevalence of hearing impairment of 1.79 per 1000 population. The prevalence of various risk factors taken into consideration was $23 \%$. Conclusion: The two staged sequential OAE assessment followed by ABR examination has an important role for the early detection of hearing impairment and consequent improvement in the quality of life. This should be adopted by all the newborn care providers as a part of their routine examination of the newborns.

Keywords: OAE (Otoacoustic emissions), ABR (Auditory Brainstem Response), Hearing assessment, Newborn.

Corresponding Author: Dr. Hemant Gupta, Assistant Professor, Department of Pediatrics, Maharishi Markandeshwar Medical College and Hospital Kumarhatti, Solan.

Received: November 2019

Accepted: November 2019

\section{Introduction}

The number of newborns with hearing loss par excels those of hypothyroidism screening at birth with an estimated prevalence of $1-3$ per $1000 . .^{[1-3]}$ The risk factors like birth asphyxia, bacterial meningitis, hyperbilirubinemia requiring exchange transfusion etc. may increase the chances of hearing loss as high as 10 to 50 times the normal. ${ }^{[3]}$ Hearing impairment has a huge adverse impact on the normal speech, language, cognitive and psychosocial outcome. ${ }^{[4-7]}$ The early infancy is the deciding period for the normal functioning of the growing auditory areas of the brain. ${ }^{[8]}$ Lack of clinical indicators further complicates the early recognition of hearing loss during this crucial period and it becomes too late during school age to intervene and improve the outcome.

Early detection of hearing impairment has been made possible with the use of universal tools like OAE (Otoacoustic emission) and ABR (Auditory brainstem response) and has resulted in the general awareness and timely intervention, if required. ${ }^{[9]}$
Most of the developed nations have imbibed the AAP guidelines of Universal newborn screening in 1999 and the ones who lag behind are on their path to adapt some consensus as per their resources to address this preventable issue. ${ }^{[10]}$

This study highlights the use of OAE and ABR for early detection of hearing loss in children 0-3 months follow up along with the associated risk factors taken into consideration.

\section{Subjects and Methods}

The present study was conducted in Maharishi Markandeshwar Medical College and Hospital, Solan, Himachal Pradesh, India over a period of one year. The study included all the hospital born neonates. After the ethical committee approval, all the inborn neonates underwent pre discharge Otoacoustic emission (OAE) examination with OAE Otolite within two days of life. The second OAE examination was done at 6 weeks of life at 
follow up immunization on the newborns who failed the first OAE examination. The second OAE failed newborns had to go through auditory brainstem response (ABR) examination with HIS-Smart EP ABR equipment by trained audiologist at 3 months of life.

The normal and admitted newborns were assessed for the risk factors which included prematurity and low birth weight $(<2.5 \mathrm{~kg})$, neonates requiring phototherapy, APGAR score of less than 4 in 1 st minute or less than 6 at 5 minutes, congenital infections, sepsis and meningitis, family history suggestive of hearing impairment, NICU admission for more than two days and those on ototoxic medications.

\section{Statistical Analysis}

The data was analyzed with SPSS software and was expressed as frequency and percentage. The chi square test and student's t test were used to clarify the relationship and two tailed value of $<0.05$ was considered significant.

\section{Results}

A total of 1680 neonates underwent pre discharge first OAE examination, $146(8.7 \%)$ failed and $1534(91.3 \%)$ passed the evaluation. For reassessment at 6 weeks of age, five neonates were lost to follow up. The remaining 141 underwent the repeat OAE examination, out of them, $23(16.3 \%)$ failed and $118(83.7 \%)$ passed the examination. [Table 1, 2]

\section{Table 1: First OAE (Otoacoustic emissions) outcome of the} study population

\begin{tabular}{|l|l|l|}
\hline First Oae & Number & Percentage \\
\hline PASS & 1534 & $91.30 \%$ \\
\hline FAIL & 146 & $8.70 \%$ \\
\hline
\end{tabular}

Table 2: Second OAE outcome of the study population

\begin{tabular}{|l|l|l|}
\hline Second Oae & Number & Percentage \\
\hline PASS & 118 & $83.7 \%$ \\
\hline FAIL & 23 & $16.3 \%$ \\
\hline
\end{tabular}

With a further loss of three newborns to turn up, 20 underwent the ABR examination. Out of the total, 17(85\%) passed and 3(15\%) failed the evaluation. [Table 3]

Table 3: ABR of the study population

\begin{tabular}{|l|l|l|}
\hline ABR & Number & Percentage \\
\hline PASS & 17 & $85 \%$ \\
\hline FAIL & 3 & $15 \%$ \\
\hline
\end{tabular}

The total of 1680 were also evaluated for the risk factors. Of the total, $388(23.1 \%)$ had one or multiple risk factors and $1292(76.9 \%)$ were without any risk factors. [Table 4]

Table 4: One or multiple risk factors of the study population

\begin{tabular}{|l|l|l|}
\hline Risk Factor & Number & Percentage \\
\hline Absent & 1292 & $76.90 \%$ \\
\hline Present & 388 & $23.10 \%$ \\
\hline
\end{tabular}

Of the total of 577 neonates with risk factors, 253(43.8\%) were preterm and low birth weight less than $2.5 \mathrm{~kg}$, $136(23.6 \%)$ required phototherapy,30(5.2\%) had APGAR score of less than 4 in 1 st minute or less than 6 in 5 minutes, $12(2.1 \%)$ had congenital infections, $86(14.9 \%)$ had more than two days of NICU stay, $5(0.9 \%)$ had family history of congenital infections, $18(3.1 \%)$ had sepsis or meningitis and 37(6.4\%) had taken ototoxic medications.[Table 5]

Table 5: Individual risk factors of the study population

\begin{tabular}{|l|l|l|}
\hline Risk Factors & $\begin{array}{l}\text { Numb } \\
\text { er }\end{array}$ & $\begin{array}{l}\text { Percent } \\
\text { age }\end{array}$ \\
\hline Preterm And Lbw & 253 & $43.8 \%$ \\
\hline Hyperbilirubinemia Requiring Phototherapy & 136 & $23.6 \%$ \\
\hline $\begin{array}{l}\text { Apgar Score Less Than 4 In 1st Minute Or Less } \\
\text { Than 6 At 5 Minutes }\end{array}$ & 30 & $5.2 \%$ \\
\hline Congenital Infections & 12 & $2.1 \%$ \\
\hline Family History Of Deafness & 5 & $0.9 \%$ \\
\hline Nicu > 2 days & 86 & $14.9 \%$ \\
\hline Sepsis And Meningitis & 18 & $3.1 \%$ \\
\hline Ototoxic Medications & 37 & $6.4 \%$ \\
\hline
\end{tabular}

Table 6: Risk factors comparison of first OAE of the study population

\begin{tabular}{|c|c|c|c|c|c|c|c|c|}
\hline Risk Factors & & $\begin{array}{l}\text { Pass } \\
\text { Number }\end{array}$ & $\begin{array}{l}\text { Fail } \\
\text { Number }\end{array}$ & Total & $\begin{array}{l}\text { Pass } \\
\text { Percentage }\end{array}$ & $\begin{array}{l}\text { Fail } \\
\text { Percentage }\end{array}$ & $\chi^{2}$ & $\begin{array}{l}\mathbf{P} \\
\text { Value }\end{array}$ \\
\hline \multirow[t]{2}{*}{ Preterm And Lbw } & Normal Term & 1287 & 105 & 1392 & $92.46 \%$ & $7.54 \%$ & 13.47 & 0 \\
\hline & Preterm And Lbw & 247 & 41 & 288 & $85.76 \%$ & $14.24 \%$ & & \\
\hline \multirow{2}{*}{$\begin{array}{l}\text { Hyperbilirubinemia Requiring } \\
\text { Phototherapy }\end{array}$} & Absent & 1431 & 124 & 1555 & $92.03 \%$ & $7.97 \%$ & 13.5 & 0 \\
\hline & Present & 103 & 22 & 125 & $82.40 \%$ & $17.60 \%$ & & \\
\hline \multirow{2}{*}{$\begin{array}{l}\text { Apgar Score Less Than } 4 \text { At } 1 \text { Minute } \\
\text { Or Less Than } 6 \text { At } 6 \text { Minutes }\end{array}$} & Absent & 1516 & 134 & 1650 & $91.88 \%$ & $8.12 \%$ & 37.73 & 0 \\
\hline & Present & 18 & 12 & 30 & $60.00 \%$ & $40.00 \%$ & & \\
\hline \multirow[t]{2}{*}{ Congenital Infections } & Absent & 1522 & 143 & 1665 & $91.41 \%$ & $8.59 \%$ & 2.44 & 0 \\
\hline & Present & 12 & 3 & 15 & $80.00 \%$ & $20.00 \%$ & & \\
\hline \multirow[t]{2}{*}{ Family History Of Deafness } & Absent & 1533 & 141 & 1674 & $91.58 \%$ & $8.42 \%$ & 42.27 & 0 \\
\hline & Present & 1 & 5 & 6 & $16.67 \%$ & $83.33 \%$ & & \\
\hline \multirow[t]{2}{*}{ Nicu >2 Days } & Absent & 1476 & 108 & 1584 & $93.18 \%$ & $6.82 \%$ & 122.5 & 0 \\
\hline & Present & 58 & 38 & 96 & $60.42 \%$ & $39.58 \%$ & & \\
\hline \multirow[t]{2}{*}{ Sepsis And Meningitis } & Absent & 1528 & 133 & 1661 & $91.99 \%$ & $8.01 \%$ & 86.4 & 0 \\
\hline & Present & 6 & 13 & 19 & $31.58 \%$ & $68.42 \%$ & & \\
\hline \multirow[t]{2}{*}{ Ototoxic Medications } & Absent & 1241 & 84 & 1325 & $93.66 \%$ & $6.34 \%$ & 43.67 & 0 \\
\hline & Present & 293 & 62 & 355 & $82.54 \%$ & $17.46 \%$ & & \\
\hline
\end{tabular}


Gupta et al; Early Detection of Hearing Lass in Children

Table 7: Risk factors comparison of the second OAE examination of the study population

\begin{tabular}{|c|c|c|c|c|c|c|c|c|}
\hline Risk Factors & & $\begin{array}{l}\text { Pass } \\
\text { Number }\end{array}$ & $\begin{array}{l}\text { Fail } \\
\text { Number }\end{array}$ & Total & $\begin{array}{l}\text { Pass } \\
\text { Percentage }\end{array}$ & $\begin{array}{l}\text { Fail } \\
\text { Percentage }\end{array}$ & $\chi^{2}$ & $\begin{array}{l}\mathbf{P} \\
\text { Value } \\
\end{array}$ \\
\hline \multirow[t]{2}{*}{ Preterm And Lbw } & Normal Term & 92 & 8 & 100 & $92.00 \%$ & $8.00 \%$ & 17.4 & 0 \\
\hline & Preterm And Lbw & 26 & 15 & 41 & $63.41 \%$ & $36.59 \%$ & & \\
\hline \multirow[t]{2}{*}{ Hyperbilirubinemia Requiring Phototherapy } & Absent & 106 & 13 & 119 & $89.08 \%$ & $10.92 \%$ & 16.21 & 0 \\
\hline & Present & 12 & 10 & 22 & $54.55 \%$ & $45.45 \%$ & & \\
\hline \multirow[t]{2}{*}{$\begin{array}{l}\text { Apgar Score Less Than } 4 \text { At } 1 \text { st Minute Or } \\
\text { Less Than } 6 \text { At } 5 \text { Minutes }\end{array}$} & Absent & 111 & 18 & 129 & $86.05 \%$ & $13.95 \%$ & 6.17 & 0.012 \\
\hline & Present & 7 & 5 & 12 & $58.33 \%$ & $41.67 \%$ & & \\
\hline \multirow[t]{2}{*}{ Congenital Infections } & Absent & 116 & 23 & 139 & $83.45 \%$ & $16.55 \%$ & 0.39 & $0.529 *$ \\
\hline & Present & 2 & 0 & 2 & $100.00 \%$ & 0.00 & & \\
\hline \multirow[t]{2}{*}{ Family History Of Deafness } & Absent & 116 & 20 & 136 & $85.29 \%$ & $14.71 \%$ & 7.24 & 0.007 \\
\hline & Present & 2 & 3 & 5 & $40.00 \%$ & $60.00 \%$ & & \\
\hline \multirow[t]{2}{*}{ Nicu > 2 Days } & Absent & 99 & 6 & 105 & $94.29 \%$ & $5.71 \%$ & 33.83 & 0 \\
\hline & Present & 19 & 17 & 36 & $52.78 \%$ & $47.22 \%$ & & \\
\hline \multirow[t]{2}{*}{ Sepsis And Meningitis } & Absent & 114 & 15 & 129 & $88.37 \%$ & $11.63 \%$ & 24.36 & 0 \\
\hline & Present & 4 & 8 & 12 & $33.33 \%$ & $66.67 \%$ & & \\
\hline \multirow[t]{2}{*}{ Ototoxic Medications } & Absent & 107 & 7 & 114 & $93.86 \%$ & $6.14 \%$ & 45.12 & 0 \\
\hline & Present & 11 & 16 & 27 & $40.74 \%$ & $59.26 \%$ & & \\
\hline
\end{tabular}

Table 8: Risk factors comparison of ABR examination of the study population

\begin{tabular}{|c|c|c|c|c|c|c|c|c|}
\hline Risk Factors & & $\begin{array}{l}\text { Pass } \\
\text { Number } \\
\end{array}$ & $\begin{array}{l}\text { Fail } \\
\text { Number }\end{array}$ & Total & $\begin{array}{l}\text { Pass } \\
\text { Percentage }\end{array}$ & $\begin{array}{l}\text { Fail } \\
\text { Percentage }\end{array}$ & $x^{2}$ & $\begin{array}{l}\mathbf{P} \\
\text { Value } \\
\end{array}$ \\
\hline \multirow[t]{2}{*}{ Preterm And Lbw } & Normal Term & 6 & 1 & 7 & $85.71 \%$ & $14.29 \%$ & & \\
\hline & $\begin{array}{l}\text { Preterm And } \\
\text { Lbw }\end{array}$ & 11 & 2 & 13 & $84.62 \%$ & $15.38 \%$ & & \\
\hline \multirow[t]{2}{*}{ Hyperbilirubinemia Requiring Phototherapy } & Absent & 11 & 1 & 12 & $91.67 \%$ & $8.33 \%$ & 1.04 & 0.306 \\
\hline & Present & 6 & 2 & 8 & $75.00 \%$ & $25.00 \%$ & & \\
\hline \multirow[t]{2}{*}{$\begin{array}{l}\text { Apgar Score Less Than } 4 \text { At } 1 \text { Minute Or } \\
\text { Less Than } 6 \text { At } 5 \text { Minutes }\end{array}$} & Absent & 13 & 2 & 15 & $86.67 \%$ & $13.33 \%$ & 0.13 & 0.717 \\
\hline & Present & 4 & 1 & 5 & $80.00 \%$ & $20.00 \%$ & & \\
\hline \multirow[t]{2}{*}{ Congenital Infections } & Absent & 17 & 3 & 20 & $85.00 \%$ & $15.00 \%$ & & \\
\hline & Present & 0 & 0 & 0 & 0.00 & 0.00 & & \\
\hline \multirow[t]{2}{*}{ Family History Of Deafness } & Absent & 15 & 3 & 18 & $83.33 \%$ & $16.67 \%$ & 0.39 & 0.593 \\
\hline & Present & 2 & 0 & 2 & $100.00 \%$ & 0.00 & & \\
\hline \multirow[t]{2}{*}{ Nicu > 2 Days } & Absent & 5 & 0 & 5 & $100.00 \%$ & 0.00 & 1.17 & 0.278 \\
\hline & Present & 12 & 3 & 15 & $80.00 \%$ & $20.00 \%$ & & \\
\hline \multirow[t]{2}{*}{ Sepsis And Meningitis } & Absent & 13 & 1 & 14 & $92.86 \%$ & $7.14 \%$ & 2.26 & 0.132 \\
\hline & Present & 4 & 2 & 6 & $66.67 \%$ & $33.33 \%$ & & \\
\hline \multirow[t]{2}{*}{ Ototoxic Medications } & Absent & 5 & 1 & 6 & $83.33 \%$ & $16.67 \%$ & 0.018 & 0.891 \\
\hline & Present & 12 & 2 & 14 & $85.71 \%$ & $14.29 \%$ & & \\
\hline
\end{tabular}

On the first OAE evaluation, out of 288 pre-terms and low birth weight neonates, 41(14.24\%) failed and 247 (85.76\%) passed the assessment; 125 neonates required phototherapy and $22(17.60 \%)$ failed; $12(40 \%)$ out of 30 had APGAR score of less than 4 in 1st minute or less than 6 in 5 minutes ;96 neonates had NICU stay more than two days with $38(39.58 \%)$ failing and 58 (60.42\%)passing the OAE examination;13 (68.42\%) out of 19 failed who had sepsis or meningitis and $62(17.46 \%)$ of 355 who were given ototoxic medications failed. All the values of comparison were statistically significant [Table 6]

On the second OAE evaluation, 15(36.59\%) out of 41 preterm and low birth weight neonates failed and 26 $(63.41 \%)$ passed the test;10(45.45\%) of 22 who required phototherapy failed and $12(54.55 \%)$ passed;5(41.67\%) of 12 who had APGAR score of less than 4 in 1st minute or less than 6 in 5 minutes failed;17(47.22\%) more than two days stay of NICU failed;8(66.67\%) who had sepsis and meningitis and 16(59.26\%) with ototoxic medications failed the second OAE examination. All the values except congenital infections were statistically significant $(p<.05)$. [Table 7]

\section{Discussion}

The developed nations are now well aware of the burden of congenital hearing loss and have taken necessary steps for its early detection whereas the developing nations like India are far behind. ${ }^{[1]]}$ Downs and Yoshingata-Itano have reported that the diagnosis of hearing loss before 6 months of age is of critical importance for the normal development of speech in neonates. ${ }^{[12]}$ Hunter MF et al has advocated for a two staged screening protocol with OAE as first screen followed by BERA for those who fail OAE screen. ${ }^{[13]}$ Indian Academy of Pediatrics has elucidated for the universal screening in early infancy as 50\% of infants with hearing loss have no risk factors and are usually discharged from well baby nursery. ${ }^{[14]}$ 
The prevalence of the failure of BERA examination of this study is 1.79 per 1000 population and is comparable to the range of 1 to as high as 8 per 1000 if the unilateral permanent hearing loss is also incorporated. ${ }^{[15,16]}$ This study showed the prevalence of neonate at high risk of 0.52 per 100.The studies done by Finitzo et al (0.5-1.0 per 100), Abraham K Paul (0.7 per 100) and James $M$ et al revealed 0.63 per 100 high risk neonates. ${ }^{[10,17,18]}$

The prevalence of the risk factors grouped together is $23 \%$ and comparable to Paul AK et al and James $\mathrm{M}$ et al with $16.63 \%$ and $21.7 \%$ respectively. ${ }^{[10,18]}$

The prevalence of separate risk factors comprises of preterms and low birth weight babies $(15 \%)$, neonates requiring phototherapy for hyperbilirubinemia (8\%), APGAR score of less than 4 in 1st minute or less than 6 in 5 minutes (15\%), congenital infections $(0.71 \%)$, family history of deafness( $0.3 \%)$,ototoxic medications $(2.2 \%)$, NICU admission for more than two days(5.1\%) and the newborn babies who had sepsis and meningitis (1.07\%).

The first OAE failure rate was $8.7 \%$ amongst the neonates. The failure rate of first OAE tested varied from $6.3 \%$ in the study done by James et al to $7.2 \%$ by De Oliveira JS et al and $12 \%$ depicted by Paul AK et al. ${ }^{[18,19]}$ The high value of our study is mainly attributed to the early pre discharge and the sample size in comparison to the other studies.

A total of 20(1.19\%) neonates failed the 2 staged sequential OAE assessment amongst the whole group as in concordance with the other studies with the approximate value of $1 \% .^{[10]}$

\section{Conclusion}

The two staged sequential OAE assessment followed by ABR examination has an important role for the early detection of hearing impairment irrespective of any risk factors. This should be adopted by all the newborn care providers as a part of their routine examination of the newborns. Newborn hearing assessment in a timely manner can impede the impairment of the quality of life of an individual.

This study had the limitation of deciding the criteria for the first assessment for OAE examination within two days which could have affected the inferences. Moreover the study group did not represent the community as a whole. Moreover prolonged duration of follow up lead to loss of some neonates albeit subtle.

\section{References}

1. Fulcher A, Purcell AA, Baker E,Munro Listen up: Children with early identified hearing loss achieve age appropriate speech/language outcomes by 3 years of age. Int $\mathrm{J}$ Pediatr Otorhinolaryngol 2012;76(12):1785-94.

2. Harrison M, Roush J, Wallace J. Trends in age of identification and intervention in infants with hearing loss. Ear Hear 2003;24(1):89-95.

3. Martines F, Martines E, Mucia M, Sciacca V, Slavago P. Prelingual sensorineural hearing loss and infants at risk: Western Sicily report. Int J Pediatr Otorhinolaryngol 2013;77(4):513-8.

4. Smith RJ, Bale JF, White KR, Sensineural hearing loss in children. Lancet 2005; 365:879-90.

5. Morton CC, Nance WE. Newborn hearing screening-a silent revolution.N Eng J Med 2006; 354:2151-64.

6. Robinshaw HM. The pattern of development from non-communicable behavior of language by hearing impaired infants.Br J Audiol 1996;30:177-98.

7. Hindley P. Psychiatric aspects of hearing impairments. J Child Psychol Psychiatry 1997;38:101-17.

8. Dominguez M, Becker S, Bruce I, Read H. A spiking neuronal model of cortical correlates of sensorineural hearing loss: Spontaneous firing, synchrony and tinnitus. Neural Comput.2006; 18:2942:2958.

9. United Nations Children s Fund (UNICEF).The state of world's children 2007.New York: UNICEF; 2008.

10. James $\mathrm{M}$ et al. A study on prevalence and risk factors of hearing impairment among newborns. Int J Contemp Pediatr.2018 Mar; 5(2):304-309.

11. White, K.R.2003. The current status of EHDI programs in the United States .Mental Retardation and Developmental Disabilities Research Reviews, 9:79-88.

12. Downs MP, Yoshingata-Itano C. The efficacy of early intervention for children with hearing impairment. Pediatr Clin North Am.1999; 46(1):79-87.

13. Hunter MF, Kimm L, Cafarlli DD, Kennedy CR, Thornton AR. Feasibility of Otoacoustic emission detection followed by ABR as a universal neonatal screening test for hearing impairment.Br $\mathrm{J}$ Audiol.1994;28:47-51.

14. Paul A, Prasad C, Kamath SS, Nair MKC, Pagarkar W. Consensus Statement of the Indian Academy of Pediatrics on Newborn Hearing Screening. Indian Pediatrics.2017; 54:647-651.

15. Stewart JE, Knorr A. Hearing loss in neonatal intensive care unit graduates: Manual of neonatal care. A Lippincott Manual. 7th ed. 2012; 65:846-50.

16. Mehra S, Eavey RD, Keamy DG Jr. The epidemiology of hearing impairment in the United States: newborns, children and adolescents. Otolaryngol Head Neck Surg.2009; 140:461-72.

17. Finitzo T, Albright K, O'Neal J. the newborn with hearing loss: detection in the nursery. Pediatrics 1998; 102: 1452-60.

18. Paul AK. Early identification of hearing loss and centralized newborn hearing screening facility: The Cochin experience. Indian Pediatr.2011; 48:355-9.

19. Oliveira JS, Rodrigues LB, Aurelio FS, Silva VB. Risk factors and prevalence of newborn hearing loss in a private healthcare system of Porto Velho, Northern Brazil. Rev Paul Pediatr.2013; 31 (3):299-305.

Copyright: (C) the author(s), 2019. It is an open-access article distributed under the terms of the Creative Commons Attribution License (CC BY 4.0), which permits authors to retain ownership of the copyright for their content, and allow anyone to download, reuse, reprint, modify, distribute and/or copy the content as long as the original authors and source are cited.

How to cite this article: Gupta H, Anand S, Grover N, Gupta V, Sharma D. Role of Otoacoustic Emissions and Auditory Brainstem Response for Early Detection of Hearing Loss in Children 0-3 Months of Age. Asian J. Clin. Pediatr. Neonatol.2019;7(4):01-04.

DOI: dx.doi.org/10.21276/ajcpn.2019.7.4.1

Source of Support: Nil, Conflict of Interest: None declared. 